\author{
Cumhuriyet İlahiyat Dergisi - Cumhuriyet Theology Journal \\ ISSN: 2528-9861 e-ISSN: 2528-987X \\ June / Haziran 2021, 25 (1): 73 - 91
}

\title{
Hanefî Fıkıh Kitaplarında Ribâ Şüphesi Kavramının Kullanımı
}

\author{
Use of the Concept 'Ribà Suspicion' in Hanafì Fiqh Books
}

\section{Huzeyfe Çeker}

Dr. Öğr. Üyesi, Necmettin Erbakan Üniversitesi, Ahmet Keleşoğlu İlahiyat Fakültesi İslam Hukuku Anabilim Dalı

Assist. Prof., Necmettin Erbakan University, Ahmet Keleşoğlu Faculty of Theology Department of Islamic Law

hceker@gmail.com

Konya / Turkey

orcid.org/0000-0002-6200-2453

\section{Article Information / Makale Bilgisi}

Article Types / Makale Türü: Research Article / Araştırma Makalesi

Received / Geliş Tarihi: 4 January / Ocak 2021

Accepted / Kabul Tarihi: 8 June / Haziran 2021

Published / Yayın Tarihi: 15 June / Haziran 2021

Pub Date Season / Yayın Sezonu: June / Haziran

Volume / Cilt: 21 Issue / Sayı: 1 Pages / Sayfa: 73 -91

Cite as / Atıf: Çeker, Huzeyfe. "Hanefî Fıkıh Kitaplarında Ribâ Şüphesi Kavramının Kullanımı [Use of the Concept 'Ribā Suspicion' in Hanafĩ Fiqh Books]". Cumhuriyet İlahiyat Dergisi-Cumhuriyet Theology Journal 25/1 (June 2021): 73 -91.

https://doi.org/10.18505/cuid.853809

Plagiarism / İntihal: This article has been reviewed by at least two referees and scanned via a plagiarism software. / Bu makale, en az iki hakem tarafından incelendi ve intihal içermediği teyit edildi.

Copyright (C) Published by Sivas Cumhuriyet Üniversitesi, İlahiyat Fakültesi / Sivas Cumhuriyet University, Faculty of Theology, Sivas, 58140 Turkey. All rights reserved.

https://dergipark.org.tr/tr/pub/cuid 
Abstract: Ribā/interest is one of the prominent regulations in Islam regarding commercial life. The commercial lives of Muslims and laws related to commerce were regulated in accordance with the prohibition of ribā, and by this a society that avoided ribā with sensitivity was created in practice. This sensitivity about ribā manifested in the principle that the suspicion of ribā is evaluated as ribā, and it is ruled as haram like riba. In fiqh sources, besides issues regarding ribā, issues involving suspicion of ribā were also mentioned, and some rulings were justified with the presence of suspicion of riba. However, the logic of using the concept of ribā suspicion in fiqh sources may vary from case to case: the reasoning behind the use of riba suspicion in one case may not fit into another case, and thus a completely different reasoning of ribā suspicion may appear in another case. To clarify the framework of the concept of ribā suspicion, it would be noteworthy to study these each of the uses in the classical fiqh sources. The purpose of this article is to examine the use of the concept of ribā suspicion based on the cases in the Hanafĩ sources. Methodologically, first, the cases in which the concept of ribā suspicion is used are determined. Secondly, the reasoning made for each example is examined by considering the contextual framework of the case. Lastly, these uses are classified and presented to the reader with examples. The principle of evaluating "the suspicion of ribā like ribā" in Islamic law is indeed related to the rule of considering "any suspicion as certainty when it comes to harams or in matters where precaution is substantial". Since ribā is a haram that Muslims should meticulously avoid, and therefore requires caution, its suspicion is subject to the same rulings as ribā itself. In the Hanafi fiqh books, the concept of suspicion of ribā is mostly referred in the following cases:

- Not knowing whether there is equality between the subject matters in barter transactions where equality is stipulated. For example, when exchanging two batches of the same kind of ribawi goods, though quantities are unknown.

- It is not known whether tariq al-itibār has taken place in changes that may be permissible through tariq al-itibār. For example, in the exchange of a silver-embroidered sword with silver, if the amount of silver in the ornamented part is not known, the suspicion of ribā arises.

- The emergence of a situation similar to ribā because of a transaction that is normally permissible: While there are two legitimate sales in Bay' al-inah, the conclusion of being the same as an interest bearing loan is considered as ribā suspicion.

- When the case has two different sides; from one side the act is ribā, but from other side it is not. For example, in the case of salam contract of ribawi goods, if goods of different quality are brought during delivery and the quality difference is requested from the customer; suspicion of ribā arises.

Apart from these uses in the Hanafi fiqh books, it is seen that the concept of ribā suspicion is employed to prove an opinion disputed between schools of Islamic law. For example, to argue that ribā rules are also valid for goods sold by piece (adadiyyāt) or by length measures (zirāiyyāt), the Hanafis say that one of the two causes (illah) of ribā is found in the exchange of these goods by type, and the suspicion of ribā arises with just a single cause (illah). On the other hand, the Shafiis use the concept of suspicion of ribā to argue that determining the subjects (ta'yin) in the exchange of ribavi goods other than gold and silver is not sufficient. Another use of the term emerges because of the authors' preference for a cautious language. Some authors acted cautiously on some cases that were normally ribā and were described by other authors in this manner, and used the term "ribā suspicion" instead of ribā; probably as they both require the same ruling (harām). Another wrongly used (in our opinion) is the use of "suspicion of ribā" in some cases that are actually considered only as disliked acts (makruh).

Keywords: Islamic Law, Islamic Law of Obligations, Ribā Suspicion, Ribā, Interest, Hanafī School of Law. 
Öz: Riba yasağı, İslam dininin ticari hayatla ilgili belirlediği temel düzenlemelerden biridir. Müslümanların ticari hayatları ve bununla ilgili hukukları ribâ yasağı gözetilerek tanzim edilmiş, tatbikatta da ribâdan hassasiyetle kaçınan bir toplum meydana getirilmiștir. Ribâ konusundaki bu hassasiyet, doktrinde ribâ şüphesinin de ribâ gibi değerlendirilmesi, ona da ribâ gibi haram hükmünün verilmesi șeklinde tezahür etmiștir. Fıkıh kaynaklarında ribânın yanı sıra ribâ şüphesi içeren meselelere de yer verilmiş, bazı meselelerin haram olması ribâ şüphesi ile gerekçelendirilmiştir. Ancak fıkıh kaynaklarında ribâ şüphesi kavramının kullanım mantığı meseleden meseleye değișebilmekte, bir meselede ribâ şüphesinin kullanıldığı mantık başka bir meseleye uymamakta, bir diğerinde ise tamamen farklı bir șekilde karşımıza çıkabilmektedir. Ribâ şüphesi kavramının çerçevesinin netleştirilebilmesi için klasik kaynaklardaki bu kullanımların bir çalışmaya konu edilmesi faydalı olacaktır. Bu amaçla kaleme alınan bu makalede Hanefî mezhebi kaynakları esas alınarak ribâ șüphesi kavramının kullanımı incelenmiștir. Bu kapsamda öncelikle ribâ șüphesi kavramının kullanıldığı meseleler tespit edilmiş, bu kullanımlar bağlamı içerisinde incelenerek kullanım mantıkları belirlenmiş, bu mantıklar tasnif edilerek örneklerle birlikte okuyucuya sunulmuştur. İslam hukukunda ribâ șüphesinin ribâ gibi değerlendirilmesi ilkesi, esasında haramlar söz konusu olduğunda veya ihtiyatın esas olduğu tüm konularda şüphenin hakikat gibi değerlendirilmesi kaidesi ile irtibatlıdır. Ribâ da müslümanların titizlikle kaçınması gereken bir haram olduğu için ve dolayısıyla ihtiyatla hareketi gerektirdiği için şüphesi de gerçek ribâ ile aynı hükme tabi kılınmıştır. Hanefî fikıh kitaplarında ribâ şüphesi kavramı daha ziyade şu durumlarda kullanılmaktadır:

- Eșitliğin șart koșulduğu bir takasta bedeller arasında eșitliğin olup olmadığının bilinmemesi: örneğin miktarları bilinmeyen iki yığın aynı cins ribevi malın değişiminde böyle bir durum söz konusudur.

- Tarîk-i itibar yoluyla caiz olabilecek bir değișimde tarîk-i itibarın gerçekleşip gerçekleşmediğinin bilinmemesi: örneğin gümüş işlemeli bir kılıcın gümüș ile takasında süslü kısımdaki gümüş miktarının bilinmemesi durumunda, bundan dolayı ribâ şüphesi meydana gelmektedir.

- Normalde caiz olan bir işlemin sonucunda ribâya benzeyen bir durumun ortaya çıkması: Bey'u'l-îne'de șekil itibariyle iki caiz satıș söz konusu iken meydana gelen neticenin faiz ile aynı olması ribâ şüphesi olarak değerlendirilmiștir.

- Aynı meseleye bir açıdan bakıldığı zaman ribâ olurken başka bir açıdan bakıldığında ribâ olmaması: Örneğin ribevi malların seleminde teslim esnasında farklı kalite mal getirilip kalite farkının müşteriden talep edilmesi durumunda bu tür bir ribâ şüphesi meydana gelmektedir.

Hanefî fıkıh kitaplarında bu kullanımların dıșında mezhepler arası ihtilaflı meselelerde bir görüşü ispat etmek için de ribâ şüphesi kavramına müracaat edildiği görülmektedir. Örneğin Hanefîler tane ile (adedî) veya uzunluk ölçüleri ile (zirâî) satılan mallarda da ribâ hükümlerinin geçerli olduğunu savunmak için bu malların cinsi cinsine değişiminde iki ribâ illetinden birisinin bulunduğunu, tek illet ile de ribâ şüphesi meydana geldiğini söylemektedir. Buna mukabil Șâfîiler de altın ve gümüș dıșındaki ribevi malların değișiminde bedellerin belirlenmiş olmasının (tayin) yeterli olmayacağını izah etmek için ribâ şüphesi kavramını kullanmaktadır. Ribâ şüphesi kavramının bir diğer kullanımı, müelliflerin ihtiyatlı bir dil tercih etmesi sonucunda ortaya çıkmaktadır. Aslen ribâ olan ve diğer müellifler tarafından da ribâ olarak nitelenen bazı meselelerde kimi yazarlar tedbirli davranmıș, muhtemelen ikisi de aynı hükmü (haram) gerektirdiği için ribâ demek yerine ribâ șüphesi tabirini kullanmıștır. Aslen mekruh olan bazı meselelerde ribâ şüphesinin bulunduğunun söylenilmiş olması şeklinde, kanaatimizce hatalı olan bir başka kullanım da kaynaklarda karşımıza çıkmaktadır.

Anahtar Kelimeler: İslam Hukuku, İslam Borçlar Hukuku, Ribâ Șüphesi, Ribâ, Faiz, Hanefî Mezhebi. 
76 | Huzeyfe Çeker. Hanefî Fıkıh Kitaplarında Ribâ Şüphesi Kavramının Kullanımı

\section{Giriş}

Ribâ, İslam borçlar hukukunun en temel meselelerinden biri olup sahabe döneminden itibaren fikıh tarihi boyunca kapsam ve mahiyeti bağlamında tartışılan bir konu olarak daima zihinleri meşgul etmiștir. İslam'ın temel yasaklarından biri olması, Hz. Peygamber (s.a.v.) tarafından yedi helak edici günah arasında sayılması, ${ }^{1}$ ribâ yasağının ihlal edilmesinin Allah'a (c.c.) ve Rasulüne (s.a.v.) savaş ilan etmekle eșdeğer tutulması ${ }^{2}$ gibi sebeplerle müslüman âlimler ribâ konusunda hassas davranmışlar; ribâ yasağını ihlal etme teşebbüslerine karşı mücadele içerisinde olmuşlardır. Ribâya karşı gösterilen bu hassasiyetin teorik yansımalarından bir tanesi de İslam hukukunda ribâ şüphesi olgusuna yer verilmesidir. Temelleri hadislere dayanan ribâ şüphesi İslam fikhında birçok meselede söz konusu edilmiş, bu meselelerde hüküm noktasında ribâ ile aynı kategoriye tabi tutulmuș, ribâdan kaçınıldığı gibi șüphesinden de uzak durulmaya gayret edilmiştir. Tüm bunlar ribâ hassasiyetinin aynen ribâ şüphesi için de gözetildiğini göstermektedir.

Öte yandan ribâ ile eşdeğer görülen ribâ şüphesinin fıkıh kitaplarındaki kullanımı konusunda bir netlik de bulunmamaktadır. Kavramın kullanım mantığı meseleden meseleye değişiklik arz etmekte, bir meseledeki kullanım biçimi diğer bazı meselelerde bulunmamakta, başka bir meselede ise bambaşka bir ribâ şüphesi kullanımı ile karşılaşılabilmektedir. Ribâ şüphesi kavramının mahiyetinin daha iyi anlaşllabilmesi için kaynaklardaki bu kullanım çeşitliliğinin bir çalışmaya konu edilmesinde fayda bulunmaktadır. Bu amaçla kaleme alınan makale boyutundaki bu araștırmada, tüm fıkıh külliyatındaki ribâ şüphesi kullanımlarını baștan sona taramak ve değerlendirmek mümkün olmadığı için Hanefî kaynaklarla yetinilecek, diğer mezheplerin kitaplarında ribâ şüphesi kavramı çok nadir kullanıldığı için çalışma kapsamına dahil edilmeyecektir. Makalede birkaç istisnası hariç verilen örneklerde gerçekte ribâ şüphesi olup olmadığı konusunda bir yargıya varmaktan kaçınılacak, bunun yerine kullanım mantıklarını tespit etmeye ve bunları bir tasnif dahilinde okuyucuya sunmaya gayret edilecektir. Konuya giriş sadedinde önce ribâ şüphesi ile ilgili kaidenin fikıh literatüründeki formlarına, diğer kaidelerle olan ilişkisine ve kaidenin nassî temellerine yer verilecek; ardından asıl konumuz olan ribâ şüphesinin kullanımlarına geçilecektir.

Ribâyla ilgili çok sayıda araştırma yapılmıș olmasına rağmen tespit edebildiğimiz kadarıyla "ribâ şüphesi" olgusunu bu açıdan inceleyen başka bir çalıșmaya rastlamadık. Münîr İbrâhîm Hindî tarafından kaleme alınan Sübhetü'r-ribâ fî muâmelâti'l-bünûki't-taklîdiyye ve'lİslâmiyye dirâse iktisâdiyye ve șer'iyye adlı bir kitap bulunmaktaysa da bu eser konuyu sadece bankacılık işlemleri açısından incelemiş olması hasebiyle bizim çalışmamızdan farklıdır.

\section{Ribâ Şüphesi Kaidesi}

\subsection{Kaidenin Fıkıh Kitaplarında Geçtiği Formları}

Ribâ ile ilgili Türkçe çalışmalarda genellikle "Ribâ şüphesi ribânın hakikati gibidir" şeklinde ifade edilen ${ }^{3}$ kaide, klasik fikıh eserlerinde çeşitli kalıplarla karşımıza çıkmaktadır. Çalıșmamız kapsamında incelediğimiz kaynaklarda genellikle "إن شبهة الربا ملحقة بالحقيقة (Ribâ

1 Ebû Abdillâh Muhammed b. İsmail el-Buhârî, el-Câmi'u's-sahîh (Dimașk-Beyrut: Dâru İbn Kesîr 2002), "Vesâyâ", 23 (No. 2766); Ebü'l-Hüseyn Müslim b. el-Haccâc el-Kuşeyrî, el-Câmi'u's-sahîh (Kahire: Dâru'l-Hadîs, 1991), “İman”, 145.

2 el-Bakara $2 / 279$.

3 Orhan Çeker, "Mecelle’de Ele Alınmayan Üç Konu: Faiz Sarf ve Karz”, Ahmet Cevdet Paşa (1823-1895) (Ankara: Türkiye Diyanet Vakfı Yayınları, 1997), 355. 
Huzeyfe Çeker. Use of the Concept 'Ribā Suspicion' in Hanafi Fiqh Books | 77

şüphesi, hakikate mülhaktır)”4 veya "الثبهة ملحقة بالحقيقة في باب الربا (Ribâ konusunda şüphe hakikate mülhaktır)”5 gibi cümlelerle karşımıza çıkan bu kaide, aynı manaya gelecek farklı cümle kalıpları ile de fıkıh kaynaklarında yer alabilmektedir. Bu başlıkta kaidenin diğer formlarına tespit edebildiğimiz kadarıyla yer vermeye çalışacağız.

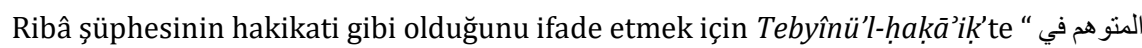
(Ribâ konusunda tereddüt edilen şey, kesin gerçekmiş gibidir)" cümlesi tercih edilmiștir. ${ }^{6}$ Bu cümleye benzer ifadeler diğer kaynaklarda da mevcut olup el-Bahru'r-râ'iḳ'te ribâ

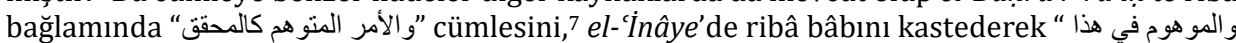
الأمر “ "المتو هم في الربا كالمحقق "ifadesini9 örnek olarak zikredebiliriz. Benzer bir başka kullanımı ise yine

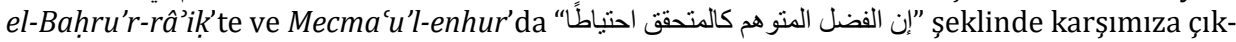
maktadır. ${ }^{10}$

Kaidenin bir diğer formu, "شبهة الربا (...) مانعة كالحقيقة (Ribâ şüphesi, hakikati gibi engeldir)" şeklinde el-Hidâye'de yer almaktadır. ${ }^{11}$ el-Bahru'r-rấ'ik’'te ise aynı cümle açıklayıcı küçük bir ilave ile "شبهة الربا (...) مانعة عن الجواز كالحقيقة şeklinde kendisine yer bulmuştur.12 Kaidenin bu ilaveli hali, el-Hidâye'deki ilgili ifadeyi șerh eden el-Binâye gibi șerhlerde de yer almaktadır. ${ }^{13}$

el-Hidâye'de bir önceki formun biraz daha yalın hali de mevcuttur. Ribâ șüphesi kaidesi bu defa, ribâya râci bir zamir ile "والثبهة فيه كالحقيقة (Ribâ konusunda şüphe hakikat gibidir)" şeklinde ifade edilmiștir. ${ }^{14}$

Ribâ şüphesinin hakikati ile aynı işleve sahip olduğu kuralı Serahsînnin (ö. 483/1090) el-Mebsûț̣ unda ihtiyat gerekçesi ile birlikte daha uzun ve açılayıcı bir şekilde ifade edilmiştir:

(Ribâda ihtiyat esastır, bundan dolayı da ribâ konusunda şüphe hakikat işlevine sahiptir.)"15

4 Mehmed b. Ferâmurz Molla Hüsrev, Dürerü'l-hükkâm fî șerhi Gureri'l-ahkâm (Karaçi: Mir Muhammed Kitabevi, ts.), 2/330; Ahmed Şemseddin Kadıâde, Netâicü'l-efkâr tekmiletü Fethi'l-kadîr (Bulak: Matbaatü'l-Kübra'l-Emîriyye, 1315), 6/149; Muhammed Emin b. Ömer b. Abdilaziz ed-Dımaşkî İbn Âbidîn, Reddü'l-muhtâr 'ale'd-Dürri'l-muhtâr șerhi Tenvîri'l-ebsâr, thk. Adil Ahmed Abdülmevcud - Ali Muhammed Muavvaz (Riyad: Dâru Âlemi'l-kütüb, 2003), 10/489; Alâüddîn Muhammed b. Muhammed Emîn ed-Dimașkî İbn Âbidînzâde, Kurretü 'uyûni'l-ahyâr tekmiletü Reddi'l-muhtâr 'ale'd-Dürri'lmuhtâr șerhi Tenvîri'l-ebsâr (Reddu'l-muhtâr ile birlikte) (Riyad: Dâru Âlemi'l-kütüb, 2003), 11/553.

5 Ebu'l-Fadl Mecdüddîn Abdullah b. Mahmûd el-Mevsılî, el-íhtiyâr li-ta'lîli'l-Muhtâr (Beyrut: Dâru'l-Kütübi'l-ilmiyye, ts.), 2/32; Kemalpașazade, Risâle fî beyâni hakîkati'r-ribâ, “İbn-i Kemâl ve 'Riba' Adlı Risalesi”, thk. Hasan Özer, İslam Hukuku Araştırmaları Dergisi 16 (2010), 179; Şeyhîzâde Abdurrahman Damad Efendi, Mecma'u'l-enhur fî șerhi Mülteka'l-ebhur (Beyrut: Dâru'l-Kütübi'l-ilmiyye, 1998), $3 / 121$.

$6 \quad$ Fahruddîn Osman b. Ali ez-Zeylaî, Tebyînü'l-hakâik fî șerhi Kenzi'd-dekâik (Bulak: Matbaatü'l-Kübra'lEmîriyye, 1315), 4/96.

7 Zeynulâbidîn b. İbrahim İbn Nüceym, el-Bahru'r-râik șerhu Kenzi'd-dekâik (Beyrut: Dârü'l-Kütübi'lilmiyye, 1997), 7/267.

8 Ekmelüddîn Muhammed b. Mahmud el-Bâbertî, el-'Inâye (Bulak: Matbaatü'l-Kübra'l-Emîriyye, 1315), 5/373.

9 İbn Âbidînzâde, Kurretü 'uyûni'l-ahyâr, 11/412.

10 İbn Nüceym, el-Bahru'r-râik, 6/225; Damad Efendi, Mecma'u'l-enhur, 3/127.

11 Ebu'l-Hasan Burhaneddin Ali b. Ebî Bekr el-Mergînânî, el-Hidâye şerhu Bidâyeti'l-mübtedî (Karaçi: İdaretü'l-Kur'an ve'l-Ulumi'l-İ́slâmiyye, 1417), 5/183.

12 İbn Nüceym, el-Bahru'r-râik, 6/213.

13 Bedrüddîn Mahmûd b. Ahmed el-Aynî, el-Binâye şerhu'l-Hidâye, thk. Emin Salih Şaban (Beyrut: Dâru'l-Kütübi'l-ilmiyye, 2000), 8/271.

14 Mergînânî, el-Hidâye, 5/197.

15 Ebû Bekir Şemsüleimme Muhammed b. Ebî Sehl es-Serahsî, el-Mebsût (Beyrut: Dâru'l-Marife, 1989), 12/178. 
78 | Huzeyfe Çeker. Hanefî Fıkıh Kitaplarında Ribâ Şüphesi Kavramının Kullanımı

Kaidenin bir diğer ifadesi, ribâ şüphesinden kaçınmanın hakikatinden kaçınmayla eşdeğer tutulması şeklinde kaynaklarda yer almıștır. Örneğin Tebyînü'l-ḥaḳảik üzerine yazılan

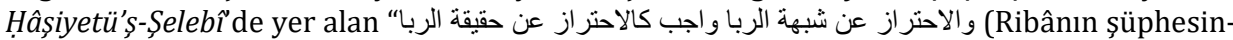
den kaçınmak hakikatinden kaçınmak gibi vacip/farzdır)" ifadesi ${ }^{16}$ aynı kaidenin farklı bir şekilde tabiri olarak değerlendirilebilir.

Ribânın șüphe ile sabit olabildiğini ifade eden bazı ibareler de ribâ șüphesi kaidesi ile doğrudan bağlantılıdır. "الربا يثبت بالثبهة (Șüphe ile ribâ sabit olur)” veya "الربا يثبت بالثبهة و التو هم (Şüphe ve vehim ile ribâ sabit olur)" gibi ifadelerle kaynaklarda yer bulan bu kullanım, ribânın şüphesinin de ribâ ile eșdeğer bir hükmü gerektirdiğini ifade etmektedir. ${ }^{17}$ Buna yakın manada bir cümle olarak "ثبوت الثبهة تكفي لثثوت حرمة الربا (Ribânın haramlığının sabit olması için şüphenin sabit olması yeterlidir)” ifadesi, Tebyînü'l-hakẩ’ $i k$ 'te karşımıza çıkmaktadır.18

Kaynaklardaki bu ifadeler her ne kadar lafız olarak birbirinden farklı olsa da ribânın şüphesinin hakikati ile aynı hükümde olduğu, ribâ haramlığının cereyan etmesi için șüphesinin bile bulunmasının yeterli olduğu hükümleri, hepsinde ortak nokta olarak vurgulanmaktadır.

\subsection{Kaidenin Diğer Kaidelerle Olan İlișkisi}

İslam hukukundaki temel ilkeleri yansıtan, farklı alanlardaki ferî meselelerin hükümlerini tamamen veya büyük oranda kuşatan tümel önermelere kaide denilmektedir. ${ }^{19}$ Külli kaide olarak da isimlendirilen bazı kaideler İslam hukukunun birçok alanındaki meseleleri içine alacak șekilde daha genel bir mahiyete sahipken alt kaide veya zâbıt olarak ifade edilen, sadece belirli fikıh konularına özgü olan daha dar kapsamlı kaideler de vardır. Bu küçük kaidelerin bir kısmı, farklı farklı konularda olmalarına rağmen ortak bir mantığa sahipseler, bu ortak mantığı ifade eden bir üst kaidenin altında da toplanabilmektedirler.

Ribâ şüphesi ile ilgili yukarıda çeşitli formlarını zikrettiğimiz kaide, sadece ribâ konusuyla sınırlı olduğu için bir alt kaide hükmündedir. Kendisi ile benzer mantığa sahip diğer kaidelerle birlikte bazı külli kaidelerin alt kaidesi olmaktadır. Ribâ șüphesi kaidesinin ilișkili olduğu, birbirine yakın anlamda olan ve biri diğerinden daha genel olan iki külli kaide bulunmaktadır: tir.)

1. الثبهة ملحقة بالحقيقة في باب الحرمات (Haramlarla ilgili konularda şüphe hakikate mülhak-

2. الثبهة تعمل عمل الحقيقة فيما هو مبني على الاحتياط (İhtiyata dayalı hususlarda şüphe, hakikatin işlevini icra eder.) $)^{20}$

Birinci külli kaide, ribânın da içinde olduğu haramların tamamında şüphenin hakikat olarak değerlendirilmesini gerektirmektedir. Sadece ribâ gibi bir konuda değil, birçok konuda geçerli olduğu için daha genel bir külli kaide hüviyetindedir. Yukarıda ifade ettiğimiz formu-

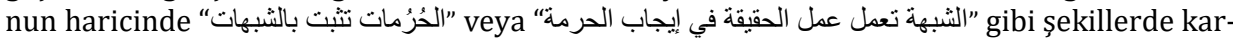
şımıza çıkan bu kaide, fıkıh ve kavâid kaynaklarında gerek ribâ gerekse de diğer haramlar

16 Ebü'l-Abbas Şehâbûddîn Ahmed b. Muhammed eş-Şelebî, Hâşiye 'alâ Tebyîni'l-hakâik (Bulak: Matbaatü'l-Kübra'l-Emîriyye, 1315), 4/87.

17 Zeylaî, Tebyînü'l-hakâik, 4/96; Kemâlüddîn Muhammed b. Abdilvâhid es-Sivâsî İbnü'l-Hümâm, Fethu'l-kadîr (Bulak: Matbaatü'l-Kübra'l-Emîriyye, 1315), 1/529; İbn Nüceym, el-Bahru'r-râik, 7/267; İbn Âbidîn, Reddü'l-muhtâr, 7/420; İbn Âbidînzâde, Kurretü 'uyûni'l-ahyâr, 11/412.

18 Zeylaî, Tebyînü'l-hakâik, 4/95.

19 Mustafa Baktır, "Kaide", Türkiye Diyanet Vakfi İslam Ansiklopedisi (İstanbul: TDV Yayınları, 2001), $24 / 205$.

20 Heyet, Ma'leme Zayed li'l-kavâ'idi'l-fikhiyye ve'l-usûliyye (Abu Dabi: Müessesetü Zayed b. Sultân, 2013), 9/221, 241. 


\section{Huzeyfe Çeker. Use of the Concept 'Ribā Suspicion' in Hanafĩ Fiqh Books | 79}

bağlamında kullanılmaktadır. ${ }^{21}$ Biri murdar biri helal kesim olan iki hayvandan hangisinin usule uygun kesildiği, hangisinin de murdar olduğu bilinmiyorsa ikisinin de etinin haram kabul edilmesi, itikâfta olan bir kimseye eşiyle ilişkiye girmesinin haram olması gibi ilişkinin öncüllerinin de haram kabul edilmesi vb. hükümler bu kaidenin pratikteki yansımalarına örnek olarak zikredilebilir. ${ }^{22}$

İkinci külli kaide, birinci külli kaideye göre daha geneldir. ${ }^{23}$ Zira sadece haramlarda değil, ihtiyatla hareket edilen tüm konularda șüphenin hakikat ile aynı işlevde olduğunu söylemektedir. Bu kaideye göre nikâh/cinsel ilişki, cezalar, ibadetler, ribâ, nesep gibi ihtiyatla hareket etmenin esas olduğu ${ }^{24}$ tüm konularda, șüphenin bulunması durumunda tedbirle hareket edilmekte, șüphe gerçekmiş gibi kabul edilmektedir. İkinci külli kaide daha genel olduğu için yukarıdaki örneklerin tamamını bu kaide kapsamında değerlendirmek de mümkündür. Ayrıca nikah șüphesi ile cinsel ilișki durumunda tedbiren iddet bekletilmesi, bir yerleșim biriminde süt kız kardeși olduğu bilinen bir adamın süt kardeșinin kimliğini bilmemesi durumunda oradaki tüm kadınların o adama haram kabul edilmesi, şüphe ile hadlerin düşürülmesi gibi hükümler bu kaidenin örnekleri arasında sayılabilir. ${ }^{25}$

\subsection{Kaidenin Nassî Temelleri}

Ribâ şüphesi kaidesi naslarda lafız olarak geçmemektedir. Ancak sünnette bu kaideye doğrudan veya dolaylı olarak delalet eden bazı beyanlar vardır. Bu başlıkta ilgili kaideye delalet ettiği düşünülen hadislerden kısaca bahsetmek istiyoruz.

Kaide ile doğrudan bağlantılı tek merfu delil, "إن النبي صلى الله عليه وسلم نهى عن الربا والريبة (Peygamber (s.a.v.) ribâyı ve șüpheyi yasakladı)" şeklindeki rivayettir. Yaptığımız araştırmalar neticesinde bu rivayetin yer aldığı bir hadis kaynağı tespit edemedik. Ancak birçok fikıh kaynağında bu rivayete yer verilmekte ve metinde geçen الريبة kelimesinden kastın ribâ şüphesi olduğu ifade edilmektedir. ${ }^{26}$

Bu merfu haberle benzer lafızda mevkuf bir rivayet, Hz. Ömer'e nispetle Sünenü İbn Mâce'de yer almaktadır. Bu rivayette bildirildiğine göre Hz. Ömer șöyle demiștir: " إن آخر ما (Kuran'dan en son nazil نزلت آية الربا، وإن رسول الله صلى الله عليه وسلم قبض ولم يفسر ها لنا، فدعوا الربا و الريبة olan ayet, ribâ ayetidir. Rasulullah (s.a.v.) bu ayeti bize açıklamadan vefat etmiștir. Öyleyse ribâyı ve şüpheyi bırakın.)"27 Bu iki rivayette ribâ ile şüphenin atıflı olarak gelmesi hükümde

21 Alâüddîn Ebû Bekir b. Mesûd el-Kâsânî, Bedâi'u's-sanâi' fì tertîbi'ş-șerâi' (Beyrut: Dâru'l-Kütübi'l-ilmiyye, 1986), 5/198; Zeylaî, Tebyînü'l-hakâik, 4/89; İbnü'l-Hümâm, Fethu'l-kadîr, 4/438; Şelebî, Hâşiye, 4/55, 87; Damad Efendi, Mecma'u'l-enhur, 3/163; Muhammed Sıdkî b. Ahmed el-Burnû elGazzî, Mevsû'atü'l-kavâ'idi'l-fikhiyye (Riyad: Mektebetü't-Tevbe, 1997), 2/51, 408, 3/109 vd.; Heyet, Ma'leme Zayed li'l-kavâ'idi'l-fikhiyye ve'l-usûliyye (Abu Dabi: Müessesetü Zayed b. Sultân, 2013), $9 / 221 \mathrm{vd}$.

22 Kaidenin örnekleri için bk. Heyet, Ma'leme, 9/225-226.

23 Heyet, Ma'leme, 9/222, 242.

24 Gazzî, Mevsû'atü'l-kavâ'idi'l-fikhiyye, 5/60.

25 Kaidenin örnekleri için bk. Heyet, Ma'leme, 9/250-252. İhtiyatla ilgili çok sayıda örnek için bk. Ali İhsan Pala, İslâm Hukukunda İhtiyat İlkesi (Ankara: Fecr Yayınları, 2009), 168-204.

26 Serahsî, el-Mebsût, 12/179; Zeylaî, Tebyînül-hakâik, 4/96; Bâbertî, el-'Inâye, 5/238; İbnü'l-Hümâm, Fethu'l-kadîr, 5/281; Şelebî, Hâșiye, 4/66.

27 Ebû Abdillâh Muhammed b. Yezid el-Kazvînî İbn Mâce, es-Sünen, thk. Beșşâr Avvâd Ma'rûf (Beyrut: Dâru'l-Cîl, 1998), “Ticarât”, 58 (No. 2276). Benzer lafızla bașka rivayetler için bk. Ebû Bekr Abdullâh b. Muhammed el-Kûfî İbn Ebî Seybe, el-Musannef fi'l-ehâdîs ve'l-âsâr (Beyrut: Dâru't-Tâc, 1989), 4/448-449 (No. 22009); Ebû Abdillâh Ahmed b. Muhammed b. Hanbel eș-Șeybânî Ahmed b. Hanbel, el-Müsned, thk. Şuayb el-Arnavut - Âdil Mürşid (Beyrut: Müessesetü'r-Risâle, 1997), 1/361 (No. 246), 425-426 (No. 350).

https://dergipark.org.tr/tr/pub/cuid 
80 | Huzeyfe Çeker. Hanefî Fıkıh Kitaplarında Ribâ Şüphesi Kavramının Kullanımı eşit olmalarını gerektirmektedir. Bu da "ribânın şüphesi hakikati gibidir" kaidesi ile aynı yargıyı ifade etmektedir.

Bu delillerin haricinde, birazdan bahsedilecek olan ribâ şüphesi kullanımı örneklerinden bazıları için vârid olmuş özel rivayetleri de kaidenin delili olarak kaydetmek mümkündür. Bu meselelerden biri, miktarı bilinmeyen yığın satışı hakkında olup konu ile ilgili özel bir rivayet bulunmaktadır. Șahîhhu Müslim ve Sünenü'n-Nesâ̂̃ de geçtiğine göre Hz. Peygamber (s.a.v.), ne kadar ölçek olduğu bilinmeyen hurma yığını ile belirli ölçekteki hurmanın değissimini yasaklamıștır. ${ }^{28}$ Hadisteki yasaklamanın gerekçesi, bedeller arasında eșitliğin olup olmadığının bilinmemesi sebebiyle ribâ şüphesidir. Dolayısıyla bu hadis, ribâ şüphesinin yasaklandığını bildiren kaidenin delilleri arasında sayılabilir.

Aynı şekilde yaş meyve ile kuru meyvenin değişimini yasaklayan hadisleri ${ }^{29} \mathrm{de}$ bu kapsamda değerlendirmek mümkündür. Zira -aşağıda daha ayrıntılı açıklanacağı üzere- bu değişimde eşitliğin sağlanamama ihtimali söz konusu olduğu için ribâ şüphesi bulunmaktadır. Dolayısıyla bu değişimi yasaklayan hadisler, ribâ șüphesinin de hakiki ribâ gibi olduğunu dolaylı olarak bildirmektedir. Bu sebeple bu hadisler de ribâ șüphesi kaidesinin delilleri arasinda zikredilebilir.

Doğrudan ribâ şüphesi kaidesi ile ilgili olmasa da şüpheli şeylerden kaçınmanın gerektiğini ifade eden genel deliller de konumuzla bağlantılı kabul edilebilir. Örneğin helal ve haramın belli olduğunu, ikisi arasındaki şüpheli şeylerden uzak durulması gerektiğini bildiren meşhur hadisi ${ }^{30}$ ribâ şüphesi konusu ile ilişkilendirmek mümkündür. Özellikle hadisteki ومن وقع في الثبهات وقع في الحرام" (Kim şüpheli şeylere düşerse harama düşmüş olur)" kısmı, ribâ şüphesinin de içinde olduğu tüm haramların şüphelerinden kaçınmayı emretmektedir. Bu açıdan ribânın şüphesinden de kaçınılması gerektiğini söylediği için kaidenin dolaylı delilleri arasında sayılabilir.

Buna benzer bir başka delil, دع ما يرييك إلى ما لا يريبك (Seni şüphelendiren şeyi bırak, şüphelendirmeyen şeye yönel) ${ }^{31}$ hadis-i şerifidir. Hz. Peygamber, riba şüphesinin de içinde olduğu tüm şüpheli şeylerden uzak durmayı emretmiștir. Dolayısıyla bu hadisi de kaidenin delilleri arasında saymak mümkündür.

Yukarıda da ifade ettiğimiz üzere riba şüphesi kaidesi, ihtiyatla hareket etmeyle ilgili külli kaidenin altında yer almaktadır. Bu açıdan bakıldığı zaman ihtiyatla hareket etmenin esas alındığı ve ilke edinildiği naslar, riba şüphesi kaidesinin dolaylı da olsa delilleri arasında kabul edilebilir. Bu kapsamda ihtiyatla ilişsili olan çok sayıda ayet ve hadisi riba şüphesi kaidesi ile ilişkilendirmek mümkündür. ${ }^{32}$

\section{Ribâ Şüphesi Kavramının Kullanıldığı Durumlar}

Hanefi mezhebi kaynaklarında ribâ şüphesi kavramı, içinde geçtiği mesele ve bağlama göre farklı durumlar için kullanılabilmektedir. Kavramın geçtiği meseleler ve kullanım mantıkları incelendiği takdirde bazılarının birbirleriyle benzer olduğu, bazılarının ise tamamen

28 Müslim, el-Câmi'u's-sahîh, "Büyû"', 42; Ebû Abdirrahmân Ahmed b. Şuayb en-Nesâî, es-Sünen (Riyad: Mektebetü'l-Meârif, ts.), "Büyû"', 37 (No. 4547): نهى رسول الله صلى الله عليه وسلم عن بيع الصبرة من التمر لا يعلم

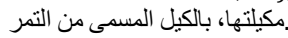

29 Buhârî, el-Câmi'u's-sahîh, "Büyû", 75, 82 (No. 2171, 2172, 2185, 2186, 2187); Müslim, el-Câmi'u'ssahîh, "Büyû"”, 59, 73, 76, 82, 83: إن رسول الله صلى الله عليه وسلم نهى عن بيع المز ابنة والمحاقلة.

30 Müslim, el-Câmi'u's-sahîh, "Müsâkât", 107.

31 Ahmed b. Hanbel, el-Müsned, 3/248-249 (No. 1723), 252 (No. 1727); Ebû Muhammed Abdullah b. Abdirrahmân ed-Dârimî, es-Sünen, thk. Hüseyin Selîm Esed el-Dârânî (Riyad: Dâru'l-Muğnî, 2000), "Büyû", 2 (No. 2574); Ebû İsâ Muhammed b. İsâ et-Tirmizî, es-Sünen (Riyad: Mektebetü'l-Meârif, 1997), "Sıfatü'l-kıyâme ve'r-rekâik ve'l-vera", 60 (No. 2518); Nesâî, es-Sünen, "Eşribe", 50 (No. 5711).

32 İhtiyatla ilgili naslar ve değerlendirmeleri için bk. Pala, İslâm Hukukunda İhtiyat İlkesi, 207-223. 


\section{Huzeyfe Çeker. Use of the Concept 'Ribā Suspicion' in Hanafĩ Fiqh Books | 81}

farklı bir bağlamda kullanıldığı görülmektedir. Bu başlık altında ribâ şüphesinin kullanıldığı durumlar tasnif edilecek, her bir alt bașlıkta ifade edilen kullanıma kaynaklardan örnekler verilecektir.

\subsection{Bedellerin Eşitliğinin Bilinmemesi}

Ribâ șüphesi kavramının en yaygın kullanıldığı durum, eșitliğin șart olduğu mübadelelerde eşitlik durumunun bilinmemesi halidir. Malum olduğu üzere ribevi malların aynı cins olanlarının değișiminde ribe'l-fadlın meydana gelmemesi için eșitlik șartı aranmaktadır. Eșitliğin şart olduğu bir mübadelede bu şartın bulunmaması ișlemin haram olmasını gerektirirken -diğer şartlarla birlikte- eşitliğin bulunması durumunda mübadele caiz olmaktadır. Böyle bir mübadelede eşitliğin olup olmadığı taraflarca bilinmez ise yapılan işlemin haram mı, yoksa caiz mi olduğu hususu da buna bağlı olarak belirsiz kalacaktır. Eşitliliğin olmaması riba olacağı için bunun belirsiz olması da riba şüphesi doğuracaktır.

Aynı cins malların götürü usulüyle (cüzafen) değişiminde bu durum söz konusudur. Örneğin miktarı taraflarca bilinmeyen iki buğday yığını takas edilmek istenirse, yığınlardaki buğday miktarının gerçekte birbirine eşit olması halinde işlem caiz, birinin diğerinden fazla olması durumunda da eşitlik şartı yerine gelmediği için ribâ olacaktır. Taraflar bu iki ihtimalden hangisinin olduğunu bilmedikleri için ribâ olma ihtimali kesinmiş gibi değerlendirilir ve bu takasın haram olduğu hükmü verilir. ${ }^{33}$ Yığınlardan birinin miktarının bilinmesi, diğerinin bilinmemesi halinde de aynı durum söz konusu olduğu için yine caiz değildir. Ancak miktarları bilinmeyen bir yığın buğday ile bir yığın arpanın takasında olduğu gibi aynı cins olmayan ve dolayısıyla eșitlik şartı aranmayan cüzafen takaslarda, eșit olmama durumu ribâ sonucunu doğurmayacağı için bu ihtimal ribâ şüphesi meydana getirmeyecek, dolayısıyla yapılan işlem caiz olacaktır. ${ }^{34}$

Naslarla yasaklanan satıșlar arasında yer alan müzâbene ve muhâkalede de benzer bir durum söz konusudur. Müzâbene, ağaç üzerinde olgunlașmıș ama henüz toplanmamıș yaș hurma ile kuru hurmanın tahminen değişimine denir. Muhâkale ise tarlada başağında bulunan henüz hasadı yapılmamıs ekinin aynı cinsten kuru mahsul ile tahminen birbirine denk olacak şekilde değiștirilmesi işlemidir. ${ }^{35} \mathrm{Bu}$ satış türlerinde aynı cins ribevi mallar değiş-tokuş edildiği için eşitlik ve peşinlik şartları aranmaktadır. Ancak yaş meyvenin kuruduğu zamanki miktarı tam olarak tespit edilemeyeceği için değişim esnasında taraflarca tahmini bir eşitlik sağlanmaktadır. Haliyle böyle bir durumda gerçek manada bir eşitliğin sağlanamama ihtimali mevcuttur. Bu ihtimalin gerçek olması durumunda ribâ sonucu meydana geleceği için ihtimalin kendisi de ribâ şüphesi olarak görülmektedir. Her ne kadar eşitliğin sağlanmış olması ihtimal dahilinde ise de tersi, ribâ şüphesi doğurduğu için kesin gerçekleşmiş gibi değerlendirilmekte ve işlemin caiz olmadığı hükmü verilmektedir. ${ }^{36}$

Klasik dönemde buğdaydan unun elde edilmesi ciddi bir zahmet ve masraf gerektirmediği için buğday ve un aynı cins kabul edilmektedir. Bu iki mal arasında aynı zamanda ölçü (keyl) birliği de bulunduğu için, birbirleri ile takas edilmeleri durumunda ölçek bazında eşitlik (hacim eșitliği) ve peşinlik şartları aranmaktadır. Ancak buğday ile unun hacim bazında

33 Muhammed b. el-Hasen eș-Şeybânî, el-Asl, thk. Mehmet Boynukalın (Beyrut: Dâru İbn Hazm, 2012), 2/418; Mergînânî, el-Hidâye, 5/11; İbn Nüceym, el-Bahru'r-râik, 5/460, 6/324; Ebû Bekir b. Ali elHaddâd, el-Cevheretünn-neyyire, thk. İlyas Kaplan (Beyrut: Dâru'l-Kütübi'l-ilmiyye, 2006), 1/435.

34 Mergînânî, el-Hidâye, 5/10-11.

35 Zeylaî, Tebyînü'l-hakâik, 4/47; Haddâd, el-Cevheretü'n-neyyire, 1/465.

36 Șeybânî, el-Asl, 2/418; Mergînânî, el-Hidâye, 5/30; Zeylaî, Tebyînü'l-hakâik, 4/47; Bâbertî, el-'inâye 5/195; Aynî, el-Binâye, 8/152; Haddâd, el-Cevheretü'n-neyyire, 1/441, 465; Sirâcüddîn Ömer b. İbrahim el-Mısrî İbn Nüceym, en-Nehru'l-fâik serhu Kenzi'd-dekâik, thk. Ahmed İzzû İnaye (Beyrut: Dâru'lKütübi'l-ilmiyye, 2002), 3/422-423; Alâüddîn Muhammed b. Ali el-Haskefî, ed-Dürru'l-muhtâr șerhu Tenvîri'l-ebsâr, thk. Abdülmünim Halil İbrahim (Beyrut: Dâru'l-Kütübi'l-ilmiyye, 2002), 415; İbn Âbidîn, Reddü'l-muhtâr, 7/255. 
82 | Huzeyfe Çeker. Hanefî Fıkıh Kitaplarında Ribâ Şüphesi Kavramının Kullanımı

eşitliğini sağlamak imkansızdır, zira buğday ögütüldüğü zaman hacmi değişmektedir. Takas edilirken un ile buğday aynı ölçüde alınsa biri diğerinden fazla olacağı için ribâ meydana gelecektir. Tahminen eșit olacak șekilde biri diğerinden fazla değişilmek istenirse bu durumda da eşitliğin sağlanmış olduğu kesin değildir. Gerçekte eșit olmama durumu ribâ olacağı için bunun ihtimali de ribâ șüphesi doğurmaktadır. Bu ihtimal kesinmiș gibi değerlendirilerek bu şekildeki bir mübadelenin caiz olmadığı hükmü verilmektedir. ${ }^{37}$

Borcun sulh ile sonlandırılması meselesindeki riba şüphesi kullanımı da bu konuyla ilişkilendirilebilir. Aralarında borç ilişkisi bulunan bireylerin borcun cinsini veya miktarını sulh yoluyla değiştirmeleri belirli şartlar dahilinde mümkündür. Tarafların vazgeçtikleri bedeli ifade eden sulh konusu (musâlah anh) ile anlaştıkları yeni bedel (sulh bedeli/musâlah aleyh) farklı cins para veya mal ise mutlak olarak cevaz verilirken, aynı cins olmaları durumunda işlemin cevazı için sulh bedelinin sulh konusundan daha fazla olmaması gerekir. Örneğin 1000 TL olan borç için tarafların 800 TL'ye sulh olmaları caiz iken 1100 TL'ye sulh olmaları caiz değildir, zira böyle bir sulh ribâ içermektedir. Ancak taraflar borç miktarını hatırlamıyorlarsa ve aynı cins bedel üzerine sulh olmak istiyorlarsa bu durumda üç ihtimal söz konusudur: Sulh bedeli ya miktarını hatırlamadıkları asıl borca eşittir, ya asıl borçtan azdır, ya da asıl borçtan daha fazladır. İlk iki ihtimalde ribâ meydana gelmeyeceği için sulh caiz olacakken, üçüncü ihtimalde ribâ meydana gelecektir. Bu üçüncü ihtimalden dolayı bu sulh ribâ şüphesi içermektedir. Bir görüşe göre bu şüphe hakikat olarak değerlendirilmekte ve bu işlem caiz görülmemektedir. Ancak sulh bedeli genelde sulh konusundan daha az olarak belirleneceği için istihsanen cevaz veren bir görüş de bulunmaktadır. ${ }^{38}$

$\mathrm{Bu}$ örneklerde görüldüğü üzere eşit olması gereken bedellerin eşit olup olmadığı bilinmiyorsa ribâya düșme endișesi sebebiyle ihtiyatla hareket edilmekte, eșit olmama ihtimali kesin olarak eşit değilmiş gibi değerlendirilerek mübadelenin caiz olmadığı sonucuna varılmaktadır.

\subsection{Tarîk-i İtibarın Gerçekleştiğinin Bilinmemesi}

İçinde ribevi mal bulunan bir bedel ile o ribevi malın cinsinden olan bir bedelin takası, ancak tarîk-i itibar yoluyla caizdir. Örneğin üzerinde 50 gram gümüş işlemesi olan demir bir kılıç, bir miktar gümüş karşılığında mübadele edilecekse bu işlemin caiz olması için ikinci bedel olan gümüșün 50 gramdan fazla olması gerekmektedir. Mesela 60 gram ile değișilmesi durumunda, tarîk-i itibar yoluyla, bu 60 gramın 50 gramının 50 gramlık gümüş işlemenin karşılığı olduğu, kalan 10 gramın da kılıcın demir kısmına karşılık geldiği kabul edilerek mübadeleye cevaz verilmektedir. Diğer bedelin gümüş ișlemeyle eșit (50 gram) belirlenmesi durumunda, kılıcın demir kısmı karşılıksız kalacağı için ribâ olur. Aynı şekilde gümüş işlemeden daha az olması durumunda demir kısmın yanı sıra işleminin de bir kısmı karşılıksız kaldığı için yine ribâ meydana gelir. ${ }^{39}$

Bu örnekteki kılıcın üzerindeki işlemede kullanılan gümüşün miktarının bilinmemesi durumunda, kılıcın gümüş ile takası ribâ şüphesi sebebiyle caiz değildir. Zira bedel olarak belirlenen gümüșten daha az olması muhtemel olduğu gibi eșit veya daha fazla olması ihtimali de vardır. İkinci ihtimalin gerçek olması durumunda ribâ sebebiyle mübadele caiz olmayacağı için bunun ihtimali de kesinmiș gibi değerlendirilmekte ve mübadele caiz görülmemektedir. Altın işlemeli eşyaların altın ile değişiminde de aynı hükümler geçerlidir. ${ }^{40}$

37 Serahsî, el-Mebsût, 12/177-178; Mevsllî, el-ihtiyâr, 2/32; Zeylaî, Tebyînü'l-hakâik, 4/95; Bâbertî, el'Inâye, 5/288; İbn Nüceym, el-Bahru'r-râik, 6/224; İbn Nüceym, en-Nehru'l-fâik, 3/479; Haskefî, edDürru'l-muhtâr, 433; İbn Âbidîn, Reddü'l-muhtâr, 7/419-420.

38 İbn Âbidînzâde, Kurretü 'uyûni'l-ahyâr, 12/336.

39 Mevslîi, el-Muhtâr, 2/40; Zeylaî, Tebyînü'l-hakâik, 4/138.

40 Ebû Bekir Alâüddîn Muhammed b. Ahmed es-Semerkandî, Tuhfetü'l-fukahâ (Beyrut: Dâru'l-Kütübi'lilmiyye, 1984), 3/32-33; Kâsânî, Bedâi'u's-sanâi', 5/195; Mergînânî, el-Hidâye, 5/276; Aynî, el-Binâye, 8/402; İbn Nüceym, el-Bahru'r-râik, 6/328. Konunun modern ve klasik problemleriyle ilgili ayrıntılı 
Huzeyfe Ceker. Use of the Concept 'Ribā Suspicion' in Hanafĩ Fiqh Books | 83

Tarîk-i itibarın gözetildiği bir diğer mesele, zeytin ile zeytinyağı takasıdır. Böyle bir değişimin caiz olması ancak tarîk-i itibar yoluyla mümkündür. Örneğin sıkıldığı zaman 2 ölçek zeytinyağı elde edilecek 10 ölçek zeytin, zeytinyağı ile takas edilecekse zeytinyağının 2 ölçekten daha fazla olması gerekir. Mesela bu zeytine bedel olarak 2,5 ölçek zeytinyağı verilse bunun 2 ölçeği zeytinin içindeki yağa, kalan yarım ölçek de yağ harici kısımlara (posaya) karşılık geleceği için mübadele caiz olacaktır. Bedelin 2 ölçek olması durumunda posa, 2 ölçekten az olması durumunda ise zeytinyağının bir kısmı ile posa karşılıksız kalacağı için ribâ meydana gelecektir. Ancak eğer zeytinin içindeki zeytinyağı miktarı bilinmiyorsa bu durumda bedel olarak takdir edilen zeytinyağının zeytinin içindeki yağdan az, eşit veya fazla olması muhtemeldir. Bu üç ihtimalin ikisi ribâ olacağı için, bu işlemde ribâ şüphesi vardır. Dolayısıyla böyle bir değişim caiz olmaz. ${ }^{41}$

Varislerden birinin terikedeki hakkından vazgeçip bir bedel üzerine sulh olması durumunda; eğer terikede, sulh bedeli ile aynı cinsten ribevi bir mal bulunuyorsa tarîk-i itibar gözetilmektedir. Örneğin terikeden kendisine düșen hissede 50 gram altın ve diğer mallar bulunan bir kişi, hissesine mukabil diğer varislerle altın karșilığında sulh yapacak olsa sulh bedelinin 50 gramdan fazla olması șarttır. Mesela sulh bedelini 60 gram olarak belirleseler bunun 50 gramı miras payındaki 50 grama, kalan 10 gram da diğer mallara tekabül edeceği için sulh caiz olur. Eğer 50 grama (veya daha aşağısına) sulh olsalar diğer mallar (ve altının bir kısmı) karșılıksız kalacağı için ribâ olur. Ancak terikede ribevi bir malın bulunduğu bilinir fakat miktarı bilinmezse, bu ribevi mal cinsinden bir bedel ile sulh yapılması ribâ şüphesi sebebiyle caiz değildir. Zira belirlenen sulh bedeli terike içindeki hisseden fazla olabileceği gibi eşit veya az olma ihtimali de vardır. Bu ihtimalin gerçek olması halinde ribâ sonucu doğacağı için ihtimali de ribâ şüphesi olur. Bundan dolayı böyle bir sulh yapmak caiz olmaz. ${ }^{42}$

Kendisine belirli bir hurma ağacının ürünü ilanihaye vasiyet edilmiş bulunan lehdârın varislerle sulh olması meselesinde de benzer bir durum vardır. Ağaçta halihazırda hurma varken vasiyet lehdârının varislerle hurma dışındaki bir keylî mal ile peşin olarak veya vezni bir mal/para ile mutlak olarak sulh olması caizdir. Ancak hurma mukabilinde sulh olsalar ribâ șüphesi olduğu için caiz değildir. Zira sulhun caiz olabilmesi için sulh bedeli olan hurmanın ağaçtaki hurma miktarından fazla olması gerekir. Örneğin ağaçta 10 ölçek hurma var ise sulh bedelinin 10 ölçekten fazla (mesela 12 ölçek) olması gerekir ki bu durumda 12 ölçeğin 10'u ağaçtaki hurmaya mukabil iken kalan 2 ölçek sonraki yıllardaki hakkını ıskat etmesine karşılık olur. 10 ölçeğe (veya daha azına) sulh olması durumunda gelecek yılların hakkının ıskatı (ve ağaçtaki hurmanın bir kısmı) karşılıksız kalacağı için ribâ olur. Ancak ağaçtaki hurma miktarı bilinmiyorsa bu durumda hurma üzerine sulh olmaları caiz değildir. Çünkü sulh bedelinin ağaçtaki hurmadan fazla olması muhtemeldir, ancak eșit veya az olması da ihtimal dahilindedir. Bu ikinci durum ribâ olacağı için buna ihtimali olan sulh da ribâ şüphesi içermektedir. Böyle bir durumda ribâ hakikaten varmış gibi hareket edilerek bu sulhun haram olduğu sonucuna varılır. 43

Bu örneklerde görüldüğü üzere ancak tarîk-i itibar yoluyla caiz olabilecek takas işlemlerinde tarîk-i itibarın olup olmadığının bilinmemesi durumunda ihtiyatla hareket edilmekte, ribâ olma ihtimali bulunduğu için ribâ șüphesi sebebiyle yapılan değișim/sulh haram kabul edilmektedir.

bilgi için ayrıca bk. Yusuf Erdem Gezgin, Altın Mübadele İşlemleri: İslam Hukuku Açısından Bir Değerlendirme (İstanbul: İktisat Yayınları, 2020), 183-216.

41 Mergînânî, el-Hidâye, 5/197.

42 Serahsî, el-Mebsût, 20/134-135; Ebû Hafs Necmüddîn Ömer b. Muhammed en-Nesefî, Tilbetü't-talebe fi'l-Istılâhâti'l-fikhiyye (Beyrut: Dâru'n-Nefâis, 1995), 295; Şelebî, Hâşiye, 5/50; İbn Âbidînzâde, Kurretü 'uyûni'l-ahyâr, 12/351-352.

43 Serahsî, el-Mebsût, 21/5.

https://dergipark.org.tr/tr/pub/cuid 


\section{4 | Huzeyfe Ceker. Hanefî Fıkıh Kitaplarında Ribâ Şüphesi Kavramının Kullanımı}

\subsection{Hükmî Fazlalık Bulunması}

Emvâl-i sitte hadisinde zikredilen altı sınıf maldan altın ve gümüşün cinsi cinsine değişiminde bedellerin eșit ve peșin, birbirleriyle değişiminde de peşin olması gerektiği hususunda mezheplerin ittifakı bulunmaktadır. Buradaki peşinlik şartının tahakkuk etmesi için tayin yeterli olmayıp kabz da şarttır. Ancak hadiste zikredilen diğer ribevi malların (buğday, arpa, tuz, hurma) değișiminde peșinliğin gerçekleșmesi için tayinin yeterli olup olmadığı hususunda Hanefî ve Şâfiî mezhepleri arasında ihtilaf bulunmaktadır. Hanefîler, bu dört sınıf malın eşya olması ve eşyaların da tayin ile teayyün etmesi sebebiyle kabza gerek olmadığını, malların belirlenmiş olması ile peşinlik şartının yerine geldiğini savunmaktadırlar. Ancak Şâfiî mezhebinde böyle bir mübadelede tayin yeterli değildir, peşinliğin gerçekleşmesi için bedellerin kabzedilmesi de zorunludur. Şâfiîlerin delillerinden birisi kabz olmadığı zaman ribâ şüphesinin bulunmasıdır. Zira akit meclisinde bedellerden birinin tayini ile yetinilir ve kabz sonraya bırakılırsa; bir bedel peşin, diğer bedel vadeli olmuş olur. Peşin olmak bir bedel için artı bir özellik sayıldığından, her ne kadar ölçek açısından rakamsal bir eşitlik olsa da peşin olan diğerine göre hükmen fazla olur. Hakiki fazlalık ribâ sonucu doğurduğu için hükmî fazlalık da ribâ șüphesi doğurur. Dolayısıyla iki bedel de kabzedilmeden yapılan mübadele caiz değildir. ${ }^{44}$

Bu örnekte görüldüğü üzere ölçek bazında rakamsal olarak bir eșitlik söz konusu olsa da hükmî bir fazlalığın bulunması ribâ şüphesi olarak değerlendirilebilmektedir.

\subsection{Ribâ İlletlerinden Sadece Birinin Bulunması}

Ribâ konusunda Hanefîler ile Şâfiîler arasındaki bir başka ihtilaf ribânın illeti konusundadır. Hanefî mezhebi cins birliği ve ölçü (vezn veya keyl) birliği şeklinde iki illet tespit ederken Şâfiî mezhebi para veya gıda maddesi olma özelliğini illet kabul etmiş; cins birliğini illet değil, ribe'l-fadl için şart görmüştür. Bu ihtilafın bir sonucu olarak Şaffî̀ mezhebinde bedellerin ikisinin de para veya gıda maddesi olması söz konusu değil ise sadece cins birliğinin bulunması hiçbir hüküm ifade etmez, değişimin ribâ olması mümkün değildir. Buna mukabil Hanefîlerde cins birliği ribânın illetlerinden biri olduğu için diğer illet olan ölçü birliği olmasa bile, diğer bir ifadeyle veznî-veznî veya keylî-keylî değişimi olmasa bile, sadece cins birliğinin bulunması ribâ hükümlerinin ișletilmesi için yeterlidir. Örneğin uzunluk birimleri ile satılan mallarda (zirâiyyât), yahut da tane ile satılan mallarda (adediyyât) cins birliği söz konusu ise ribâ illetlerinden biri olduğu için değişimin -eşit olmasa da- peşin olması şarttır. Bunun sonucunda bir Herevî elbisenin iki Herevî elbise ile veya bir hayvanın aynı cins başka bir hayvanla vadeli değişimi Hanefîlerde nesie ribâsı sonucu doğurmaktadır. Şâfiî mezhebi ise ribevi mallar dışındaki değişimlerde cins birliğini dikkate almadığı için bu mübadelelere cevaz vermektedir. 45

Hanefîlerin bu görüșlerini izah ederken ileri sürdükleri delillerden bir tanesi, ihtilaf edilen meselede ribâ șüphesinin bulunduğu șeklindedir. Onlara göre bir mübadelede illetlerin her ikisi de bulunursa hakiki anlamda ribâ meydana gelirken illetlerinin sadece birinin bulunması ribâ şüphesi meydana getirir. Bu konuda ribâ şüphesi de hakikati gibi değerlendi-

44 Mergînânî, el-Hidâye, 5/186-187; Bâbertî, el-'Inâye, 5/284-285; Damad Efendi, Mecma'u'l-enhur, 3/121-122. Şafiî kaynaklardan ilgili konu için bk. Ebü’l-Hasen Ali b. Muhammed el-Mâverdî, el-Hâvi'lkebîr, thk. Adil Ahmed Abdülmevcud - Ali Muhammed Muavvaz (Beyrut: Dâru'l-Kütübi'l-ilmiyye, 1994), 5/77-78; Ebu'l-Muzaffer Mansûr b. Muhammed es-Sem'ânî, el-İstılâm fi'l-hilâf beyne'lİmâmeyn eş-Şâfi î ve Ebî Hanîfe, thk. Nâyif b. Nâfi' el-Ömerî (Kahire: Dâru'l-Menâr, 1992), 3/63-67; Ebû Zekeriyya Yahyâ b. Șeref en-Nevevî, el-Mecmû' șerhu'l-Mühezzeb (Dâru'l-Fikr, ts.), 9/403.

45 Ebû Abdillâh Muhammed b. İdris eș-Şâfiî, el-Ümm (Beyrut: Dâru'l-Marife, ts.), 3/99; Ebû İbrâhîm İsmâîl b. Yahyâ el-Müzenî, el-Muhtasar (Beyrut: Dâru'l-Kütübi'l-ilmiyye, 1998), 109; Mâverdî, elHâvi'l-kebîr, 5/100. Hanefî kaynaklar için bir sonraki dipnota bakınız. 
Huzeyfe Çeker. Use of the Concept 'Ribā Suspicion' in Hanafi Fiqh Books | 85

rildiği için sadece bir illetin bulunduğu meselelerde de ribâ hükümlerini işletmek mümkündür. Dolayısıyla zirâî ve adedî malların cinsi cinsine takasında riba şüphesinin meydana gelmemesi için değişimin peșin olarak yapılması gerekir. ${ }^{46}$

Hanefîlerin bu izahı ribânın illetlerinden sadece birinin (cins birliği) bulunması durumunda yapılacak vadeli işlemin ribâ şüphesi kapsamında değerlendirildiğini göstermektedir.

\subsection{Bir Açıdan Ribâ Olup Bir Açıdan Olmama Durumu}

Fıkıh kitaplarında ribâ şüphesinin bir diğer kullanımı, iki açıdan bakılabilen bazı meselelerde karșımıza çıkmaktadır. Bir meseleye bir açıdan bakıldığında ribâ oluyor, ancak başka bir açıdan bakıldığında caiz oluyorsa bu durum ribâ şüphesi ile ifade edilebilmektedir. Bunun güzel bir örneği, selem akdinde siparișin teslimi esnasında müslemün ileyhin/selem satıcısının yakın evsafta bir mal getirmesi ve selem bedeline (ra'sü'l-mâle) ilave yapmayı veya bir kısmını geri almayı teklif etmesi durumunda ortaya çıkmaktadır. Şöyle ki; mesela 10 dirhem karşılığında 10 ölçek orta kalite buğday üzerine selem akdi yapan müslemün ileyh, teslim zamanı 10 ölçek daha kaliteli buğday getirse ve "bunu vereyim ama 1 dirhem fazla isterim" dese Ebû Hanîfe (ö. 150/767) ile İmam Muhammed'in (ö. 189/805) görüşüne göre bu akit caiz olmaz. Onlara göre bu meseleye iki açıdan bakmak mümkündür. Birincisine göre, teslim esnasında hazır bulunan 10 ölçek kaliteli buğday, müslemün ileyhin zimmetindeki 10 ölçek orta kalite buğday ve 1 dirhem karşılığında değiștirilmiş olmaktadır. Böyle bir değişimde kalite farkı dikkate alınmayacağı için 1 dirhem fazlalık karşılıksız kalmakta ve ribâ söz konusu olmaktadır. Ancak bu akitte netice itibariyle 11 dirhem karşılığında 10 ölçek kaliteli buğday üzerine selem akdi yapılmıș olur ki bu açıdan bakıldığında yapılan işlem caiz olmaktadır. Bir açından ribâ olması ama diğer açıdan ribâ olmaması, ribâ şüphesidir. ${ }^{47}$ Aynı mesele tersten olursa, yani 10 dirhem karşılığında 10 ölçek kaliteli buğday üzerine selem yapan müslemün ileyh, teslim esnasında 10 ölçek orta kalite buğday getirse ve "Bunu al, bir dirhem iade edeyim" dese yine aynı ihtilaf söz konusu olup Ebû Hanîfe ve İmam Muhammed, aynı izahı yaparak ribâ şüphesi gerekçesiyle cevaz vermemektedir.48

Bu durumun bir bașka örneği zekât tahakkuk eden para ile zekât verilen para arasında ayar farkının bulunması durumudur. Örneğin normal ayarda 200 dirhem gümüșe sahip olan bir kimse, zekât borcu tahakkuk edince, 4 normal dirhem değerinde ayarı düșük 5 dirhem verse zekatını vermiș olur mu meselesinde Ebû Hanîfe ile Ebû Yûsuf (ö. 182/798) zekâtın verilmiş olduğu görüşünde iken, İmam Muhammed ayarı düşük 5 dirhemin yeterli olmayacağını, ilaveten 1 dirhem daha vermek gerektiği kanaatindedir. İhtilafın temelinde zekât veren zengin ile fakirin "akit yapan iki kişi (müteâkideyn)" gibi olup olmamasının belirsizliği yatmaktadır. Yapılan ișlemin mahiyeti incelendiğinde müteâkideyn olmalarını gerektirecek veriler olduğu gibi böyle olmadıklarını gösteren ișaretler de bulunmaktadır. Eğer müteâkideyn olarak kabul edilirse zekât verme işlemi akit gibi olacağı için ribâ olmasın diye kalite farkının dikkate alınmaması gerekmektedir. Bu durumda 5 dirhemden daha fazlası verilirse 5 dirhem ile fazlasının değiștirilmesi gibi bir durum olacağı için ribâ sonucu doğuracaktır. Müteâkideyn kabul edilmemeleri durumunda ise ribâ ihtimali kalmadığı için kalite farkı dikkate alınabilecek, verilen 5 dirhemin değeri düşük olduğu için fark olarak bir dirhem daha vermek gerekecektir. İmam Muhammed, müteâkideyn kabul edip etmeme durumlarından hangisi fakirin le-

46 Bâbertî, el-'Inâye, 5/279-280; Mehmed b. Ferâmurz Molla Hüsrev, Dürerü'l-hükkâm fî șerhi Gureri'lahkâm (Karaçi: Mir Muhammed Kitabevi, ts.), 2/186; Selebî, Hâsiye, 4/87; Damad Efendi, Mecma'u'lenhur, 3/121. Ayrıca bk. Mergînânî, el-Hidâye, 5/182-183; Aynî, el-Binâye, 8/270-271; Kemâlüddîn Muhammed b. Abdilvâhid es-Sivâsî İbnü'l-Hümâm, Fethu'l-kadîr (Bulak: Matbaatü'l-Kübra'lEmîriyye, 1315), 5/280; İbn Nüceym, el-Bahru'r-râik, 6/213.

47 Mahmûd b. Ahmed el-Merğînânî Burhânüddîn el-Buhârî, el-Muhîtu'l-Burhânî (Beyrut: İdâretü'lKur'ân ve'l-ulûmi'l-İslâmiyye, 2004), 10/298-299.

48 Burhânüddîn el-Buhârî, el-Muhîtu'l-Burhânî, 10/299-300. 
86 | Huzeyfe Çeker. Hanefî Fıkıh Kitaplarında Ribâ Şüphesi Kavramının Kullanımı

hine ise ona göre meseleyi çözümlemekte iken Ebû Hanîfe ile Ebû Yûsuf ribâ şüphesi ile meseleyi izah etmeyi tercih etmiştir. Onlara göre taraflar bir açıdan müteâkideyn olup bir açıdan olmadıkları için yapılan işlem de bir açıdan ribâ olmakta, bir açıdan ise olmamaktadır. Bu da meselenin ribâ şüphesi içerdiği manasına gelir. Ribâ şüphesi de hakikati olarak değerlendirildiği için meselemiz bir ribevi muamele olmakta, ribevi muamelelerde de ayar farkı dikkate alınmadığı için ayarı düşük de olsa 5 dirhem vermekle zekat borcu ifa edilmiş olmaktadır. ${ }^{49}$

Bu izahlar göstermektedir ki bir mesele bir açından ribâ, diğer bir açıdan caiz ise ribâ şüphesi içerdiği ifade edilebilmektedir. Bunun sonucu olarak da hakikaten ribâ varmış gibi değerlendirilerek ișlemin caiz olmadığı söylenebilmektedir.

\subsection{Caiz Bir İşlemin Sonucunun Ribâya Benzemesi}

İslam hukukunda caiz kabul edilen bir ișlemin neticesinde ortaya çlkan durum, eğer ribâyla benzerlik arz ederse bu durumda da ribâ şüphesi kavramı kullanılabilmektedir. Örneğin satışı gerçekleșmiş ama teslim edilmemiş kölenin üçüncü bir şahıs tarafından öldürülmesi meselesinde böyle bir kullanım vardır. Mesela 2000 dirhem değerindeki bir köle 1000 dirheme satılsa, ancak teslimden önce bir yabancı kiși köleyi öldürse, müşteri dilerse kölenin değeri olan 2000 dirhemi kâtilden alır. Çünkü mülkiyetinde olan mal, birisi tarafından telef edilmiștir ve kıymeti üzerinden tazmin ettirme hakkı vardır. Ancak ortada henüz teslim almadığı, tasarruf hakkının henüz başlamadığı, kendi damanına bile girmemiş bir maldan kâr elde etmiş olması durumu söz konusu olur ki bu hadisle yasaklanmıștır. Ayrıca her ne kadar yapılan tazmin, kurallara uygun olsa da neticede mal hiç eline geçmediği için adeta 1000 dirhem verip 2000 dirhem almış gibi olur ki bu ribâya benzediği için ribâ șüphesi doğurur. Bu iki gerekçeden hareketle, müșterinin kâtilden aldığı 2000 dirhemden 1000 dirhemi satıș bedeli olarak satıcıya vermesi, kalan 1000 dirhemi ise ihtiyaç sahiplerine dağıtması gerekir. ${ }^{50}$

Bu kullanımın bir başka örneğine îne satışının (بيع العينة) izahında rastlanılmaktadır. Vadeli olarak satılan bir malın satıcıya daha ucuza peșin olarak geri satılması veya peșin olarak satın alınan bir malın aynı kișiye vadeli olarak daha pahalıya geri satılması șeklinde olan îne satışında aslında biri peşin, diğeri vadeli olan iki tane satış işlemi yapılmaktadır ki bu satıșlar normalde caiz olan ișlemlerdir. Ancak aynı malın karşı tarafa gidip daha sonra aynı kişiye geri gelmiş olması sebebiyle, netice itibariyle satış bedellerinin mübadele edilmesine benzer bir durum ortaya çıkmaktadır. Örneğin bir saat 1000 TL'ye vadeli olarak satılıp hemen ardından peșin 800 TL'ye satıcıya geri satılacak olursa, saat akitlerin bașında ve sonunda aynı kişide (satıcıda) olacağı için netice itibariyle vadeli 1000 TL ile peșin 800 TL'nin mübadelesi gibi bir durum meydana gelmektedir. Böyle bir mübadele ribâ olduğu için bunun benzerinin bulunduğu îne satışında da ribâ şüphesi oluşmaktadır. Bu sebeple bu işlemin caiz olmadığını söylemek mümkündür. 51

Îne satıșına benzer bir durum, satıcının satıp henüz parasını almadığı bir malı, müșteriden bașka bir malla birlikte aynı fiyata geri alması meselesinde de bulunmaktadır. Hanefî fıkıh literatüründe bu mesele genelde cariye örneği üzerinden anlatılmaktadır. 500 dirheme satılmıș bir cariye, henüz parası teslim alınmadan bașka bir cariye ile birlikte yine 500 dirheme satıcıya geri satılsa bu caiz değildir. Aslında burada taraflar tüm şartları yerinde olan iki tane bey' akdi yapmışlardır. Akitler müstakil olarak düşünüldügü zaman caiz olmamaları için bir sebep bulunmamaktadır. Ancak iki ișlem beraber düșünüldüğünde; ikinci akitte mebiye ilave edilen cariye, semenin az da olsa bir kısmına tekabül edeceği için iki satışa da konu olan diğer cariye 500'e satılmıș ama 500'den daha aşağıya geri alınmıș olmaktadır. Bu durum

Kâsânî, Bedâi'u's-sanâi', 2/42; Burhânüddîn el-Buhârî, el-Muhîtu'l-Burhânî, 2/244-245.

50 Serahsî, el-Mebsût, 13/172; Kâsânî, Bedâi'u's-sanâi', 5/238-239.

51 Kâsânî, Bedâi'u's-sanâi', 5/198-199; Burhânüddîn el-Buhârî, el-Muhîtu'l-Burhânî, 9/381; Ebû Muhammed Muvaffakuddîn Abdullâh b. Ahmed İbn Kudâme, el-Muğnî, thk. Abdulfettâh el-Hulv - Abdullah et-Türkî (Riyad: Dâru Âlemi'l-kütüb, 1997), 6/260-261. 
Huzeyfe Çeker. Use of the Concept 'Ribā Suspicion' in Hanafĩ Fiqh Books | 87

da yukarıda îne satışında anlattığımız durumu doğurmakta ve ribâ şüphesi meydana getirmektedir. İki işlemin bir bütün halinde ribâya benzemesi şöyle de ifade edilebilir: İlk satılan cariye en baștaki sahibine geri döndügü, ilk akdin borcu olan 500 de ikinci akdin bedeli olan 500 ile mahsuplaşıldığı için adeta hiç akde dahil olmamış gibi olmakta; dolayısıyla ikinci satıșta mebiye ilave edilen cariye karșılıksız kalmaktadır. İșlemin tamamında karșılıksız bir fazlalık bulunduğu için ribâya benzer bir durum ortaya çıkmaktadır. Caiz işlemler neticesinde ribâya benzer bir durum ortaya çıktığı için bu meselede ribâ şüphesi meydana gelmektedir. ${ }^{52}$

Bu örneklerde görüldüğü üzere bir işlem her ne kadar şeklen caiz olsa da netice itibariyle ribâya benzer bir durum ortaya çıkarıyorsa, bu işlemin ribâ şüphesi ihtiva ettiği söylenebilmekte, dolayısıyla da caiz olmadı̆̆ yargısına varılabilmektedir.

\subsection{Ribâ Şüphesi Kavramının Diğer Kullanımları}

Ribâ şüphesi kavramı, fıkıh kaynaklarında yukarıdaki sayılanların haricinde de çeşitli amaçlarla kullanılmıştır. Ancak kanaatimizce bunlar hakiki ribâ olarak görülmesi gereken ribâ şüphesi kapsamında değildir. Bu başlıkta esasında ribâ şüphesi kapsamında olmaması gerektiğini düşündüğümüz diğer kullanımlara yer vereceğiz.

Bu kullanımların ilkinde, müelliflerin, aslında ribâ olan bir meselede kısmen tereddüt yaşamaları veya ihtiyatlı ifade kullanmak istemeleri sebebiyle meseleyi doğrudan ribâ olarak nitelemek yerine -muhtemelen zaten ribâ ile aynı hükmü gerektireceği için- ribâ şüphesi kavramını kullandıkları görülmektedir. Örneğin Kâsânî (ö. 587/1191), karz akdi esnasında şart koşulan menfaat konusunu anlatırken bir menfaatin şart koşulmasını, karşılığı olmayan bir fazlalık olduğu için ribâya benzetmiş, ardından hem ribâdan hem de ribâ şüphesinden kaçınmak gerektiğini söylemiştir. ${ }^{53}$ Ancak diğer kaynaklarda belirtildiği üzere borç verirken menfaat içeren bir şartın ileri sürülmesi ribânın şüphesi değil, doğrudan ribânın kendisidir. ${ }^{44}$ Dolayısıyla bu konuda ribâ şüphesi kavramının kullanımı kanaatimizce isabetli değildir. Bu durumu müellifin ihtiyatlı bir ifade kullanma isteğiyle izah etmek mümkündür.

Buna benzer bir durum, taraflardan birine karşıllksız menfaat sağlayan örfleşmemiș şartlar konusunda mevcuttur. Birçok Hanefî kaynakta ifade edildiği üzere, mezhebin ca'lî şartlar teorisine göre, ıvazlı akitlerde bu tür şartlar ileri sürüldüğü zaman karşılıksız bir menfaat olduğu için "ribâ" meydana gelmektedir.55 Ancak Hanefî literatürünün önemli eserlerinden Tuhfetüll-fukahâa ve Bedâ'i 'u'ș-șanâ'i $i^{\circ}$ de taraflardan birine menfaat sağlayan bu şartların "ribâ veya ribâ şüphesi" doğurduğu ifade edilmiştir. ${ }^{56}$ Bu iki eserde ribâ şüphesinin ribâ ile birlikte zikredilmiş olması ve hemen ardından "ribâ şüphesinin ribâ ile aynı hükümde" olduğunun vurgulanması, müelliflerin ihtiyatlı bir dil kullandıklarını, her ikisi de aynı hükmü gerektirdiği için ribâ ile ribâ şüphesi ayrımını dikkate almadıklarını göstermektedir.

Ribâ yerine ribâ şüphesi kavramının kullanımın bir diğer örneği, ayrılmayan bir ilave (ziyâde-i muttasıla) yapılmış mebide ayıp tespit edilmesi meselesinde görülmektedir. Müşteri

52 Mergînânî, el-Hidâye, 5/116-117; Bâbertî, el-İnâye, 5/210; Aynî, el-Binâye, 8/175-176; İbnü'lHümâm, Fethu'l-kadîr, 5/210-211; Molla Hüsrev, Dürerü'l-hükkâm, 2/172; İbn Nüceym, el-Bahru'rrâik, 6/137-138; Șelebî, Hâșiye, 4/55-56; İbn Âbidîn, Reddü'l-muhtâr, 7/270-271.

53 Kâsânî, Bedâi'u's'sanâi', 7/395.

54 Mâverdî, el-Hâvi'l-kebîr, 6/246; Serahsî, el-Mebsût, 14/35; Ebû Abdillâh Şemsüddîn Muhammed b. Ahmed er-Remlî, Nihâyetü'l-muhtâc ilâ șerhi'l-Minhâc (Beyrut: Dâru'l-Kütübi'l-ilmiyye, 2003), 4/230; Şelebî, Hâșiye, 6/29.

55 Mergînânî, el-Hidâye, 6/265; Zeylaî, Tebyînül-hakâik, 4/57, 131; Bâbertî, el-'inâye, 5/225; İbnü'lHümâm, Fethu'l-kadîr, 2/464; Molla Hüsrev, Dürerü'l-hükkâm, 2/199-200; İbn Nüceym, el-Bahru'rrâik, 6/208, 298; İbn Âbidîn, Reddü'l-muhtâr, 7/190, 233, 399. Tek tarafa yarar sağlayan ca'lî șartlar ile ilgili geniş bilgi için bk. Mahmut Samar, Akitlerde Şart Hürriyeti (Kahramanmaraş: SAMER Yayınlarl, ts.), $106 \mathrm{vd}$.

56 Semerkandî, Tuhfetü'l-fukahâ, 2/53; Kâsânî, Bedâi'u's-sanâi', 4/195. 
88 | Huzeyfe Çeker. Hanefî Fıkıh Kitaplarında Ribâ Şüphesi Kavramının Kullanımı satın aldığı mebiye muttasıl ziyade yaptıktan sonra ayıplı olduğunu fark ederse, ayıp muhayyerliği gerekçesiyle iade imkânı yoktur. Sadece satıcıdan aybın değerini isteme hakkı vardır. Müşteri yaptığı ziyadeden vazgeçmeyi kabul etse bile iade mümkün değildir. Zira böyle bir durumda satıcı ziyadeyi karşıllkssız olarak elde etmiş olur ki birçok Hanefî kaynakta bu fazlalık ribâ olarak nitelenmiştir. ${ }^{57}$ Ancak bazı Hanefî kaynaklarda iadenin mümkün olmaması, ribâ ile beraber ribâ şüphesi ile de temellendirilmiştir. Örneğin Fethu'l-kadîr ve ondan alıntı yapan Reddü'l-muhtâr'da mesele önce doğrudan ribâ temelinde izah edilmiș iken bir yerde "ribâ veya ribâ şüphesi" ifadesi kullanılmıș, yukarıdaki benzerlerinde olduğu gibi hemen ardından ribâ şüphesinin ribâ ile aynı hükümde olduğu ifade edilmiștir. ${ }^{58}$ Bu durum Fetḥu'l-kadîr müellifi İbnü'l-Hümâm'ın (ö. 861/1457) ihtiyatlı bir dil kullandığına ișaret etmektedir. elHidâye'nin aynı dönemde yazılmış bir başka șerhi olan el-Binâye'nin müellifi Aynî (ö. 855/1451) ise, meseleyi doğrudan ribâ şüphesi ile gerekçelendirmeyi tercih etmiş, ancak izahına girmemiștir. ${ }^{59}$ Tüm bu veriler, iadenin imkansızlığının aslında ribâya dayandığını, ancak bazı müelliflerin ribâ yerine ribâ şüphesi ifadesini kullandıklarını göstermektedir.

Ribâ şüphesi kavramı, kelime manası ile bağlantılı olarak ribâ olup olmadı̆̆ı tartışmalı hususlarda da kullanılabilmektedir. Ancak buradaki ribâ şüphesinin önceki başlıklarda sayılan ribâ şüphesi kullanımlarından farkı, ribâ ile aynı hükmü gerektirip gerektirmediği noktasındadır. Yukarıdaki kullanımların hepsinde ribâ şüphesi, ribâ ile aynı hükmü (haram) gerektirmekte iken bu son kullanımda meselenin hükmü haram değil, mekruh olmaktadır. Bu açıdan bakıldığında bu meselelerde ribâ şüphesi kavramının kullanılmış olması kanaatimizce doğru değildir. Zira bir meselede hem ribâ șüphesi var denilip hem de mekruh olduğunu söylemek kendi içinde çelișki barındırmaktadır. Eğer gerçek manada bir ribâ şüphesi olsaydı hükmünün de haram olmasını gerektirirdi. Mekruh denilmiş olması bunun ribâ şüphesi olmadığını göstermektedir. Bu șekilde hatalı kullanım nadiren karșımıza çıkmakta olup taradığımız kaynaklarda sadece iki örneğine rastladık. Birincisinde Ġamzü 'uyûni'l-beșẩir müellifi Hamevî (ö. 1098/1687), rehin malın rahinin izni ile mürtehin tarafından kullanılmasının ribâ şüphesi sebebiyle mekruh olduğunu ifade etmektedir. ${ }^{60}$ İkincisi ise el-Fetâva't-Tatarhâniyye ve el-Fetâva'l-Hindiyye'de geçmekte olup aktarıldığına göre Muhammed b. İbrahim elMeydânî (ö. IV/X. yüzyıl) ribâ şüphesi içerdiği için vefâen satışı mekruh görmektedir. ${ }^{61}$

57 Kâsânî, Bedâi'u's-sanâi', 5/286; Zeylaî, Tebyînül'-hakâik, 4/35; Bâbertî, el-'̇nâye, 5/160; Molla Hüsrev, Dürerü'l-hükkâm, 2/162; Damad Efendi, Mecma'u'l-enhur, 3/66; Haskefî, ed-Dürru'l-muhtâr, 408; Abdulganî el-Ganîmî el-Meydânî, el-Lübâb fî șerhi'l-Kitâb (Beyrut: el-Mektebetü'l-İlmiyye, ts.), 2/2122.

58 İbnü'l-Hümâm, Fethu'l-kadîr, 5/160; İbn Âbidîn, Reddü'l-muhtâr, 7/190.

59 Aynî, el-Binâye, 8/112.

60 Ebü'l-Abbâs Șihâbüddîn Ahmed b. Muhammed el-Hamevî, Gamzü 'uyûni'l-besâir șerhu kitâbi'l-Eșbâh ve'n-nezâir (Beyrut: Dâru'l-Kütübi'l-ilmiyye, 1985), 3/244.

61 Ferîdüddin Âlim b. el-Alâ el-Enderpetî, el-Fetâva't-Tatarhâniyye (Diyobend: Mektebetü Zekeriyyâ, 2010), 15/333; Heyet, el-Fetâva'l-Hindiyye / el-Fetâva'l-Âlemgîriyye (Bulak: Matbaatü'l-Kübra'lEmîriyye, 1310), 6/309. 
Sonuç

Ribâ şüphesi kavramının Hanefî fıkıh kitaplarındaki kullanımlarını tespit etmek üzere yapılan bu çalıșmanın neticesinde, ilgili kavramın daha ziyade şu durumlarda kullanıldığı tespit edilmiştir:

- Eşitliğin şart olduğu değişimlerde eşitliğin bulunup bulunmadığının bilinmemesi,

- Tarîk-i itibar yoluyla caiz olabilecek bir değișimde tarîk-i itibarın bulunup bulunmadığının bilinmemesi,

- Caiz bir işlem neticesinde ortaya çıkan durumun ribâya benzemesi,

- Aynı meseleye bir açıdan bakıldığı zaman ribâ olurken başka bir açıdan bakıldığında caiz sonuç doğurması,

Bu durumların haricinde ihtilaflı meselelerde görüş sahiplerinin kendi görüşlerini ispat etmek için ribâ şüphesi kavramına müracaat ettikleri de görülmektedir. Hanefîler ile Şâfiîler arasındaki ihtilaflı iki meselenin birinde Şâfiîler hükmî fazlalık bulunmasını ribâ şüphesi ile ilişkilendirirken, diğerinde iki ribâ illetinden sadece birinin bulunması durumu Hanefîler tarafından ribâ șüphesi olarak nitelendirilmiştir.

Ribâ ile ribâ şüphesinin her ikisinin de haram sonucu doğurması sebebiyle, aslen ribâ olan bazı meselelerde müelliflerin ihtiyatlı bir dil kullanarak ribâ demek yerine ribâ şüphesi dedikleri de söz konusu olabilmektedir. Ayrıyeten, kanaatimizce hatalı bir kullanım olarak, mekruh görülen bazı hususlarda da ribâ şüphesi kavramının kullanıldığı görülmektedir.

Çalışma esnasında dikkatimizi çeken bir başka husus, ribâ şüphesi ifadesinin daha ziyade Hanefî kaynaklarda kullanılmıș olmasıdır. Aynı meselelerde diğer mezheplerin kullandığı zerî́a ile'r-ribâ, ihtimâlü'r-ribâ gibi kavramlar yeni bir çalıșmaya konu edilebilir.

Ayrıca çalışmamızda ribâ şüphesi kavramının kaynaklardaki kullanım mantıklarına yoğunlaşılmış, bu kullanımların doğru olup olmadığı hususunda yargıda bulunmaktan genel olarak kaçınılmıştır. Dolayısıyla ribâ şüphesi kavramı üzerine doktora tezi düzeyinde bir çalışma yapılarak kavramın mahiyeti tespit edilebilir, ribâ şüphesi olmadığı halde kaynaklarda bu şekildeki nitelemelerin söz konusu olup olmadığı konusunda değerlendirmeler yapılabilir. 
90 | Huzeyfe Çeker. Hanefî Fıkıh Kitaplarında Ribâ Şüphesi Kavramının Kullanımı

\section{Kaynakça}

Ahmed b. Hanbel, Ebû Abdillâh Ahmed b. Muhammed b. Hanbel eş-Şeybânî. el-Müsned. thk. Şuayb el-Arnavut - Âdil Mürşid. Beyrut: Müessesetü'r-Risâle, 1997.

Aynî, Bedrüddîn Mahmûd b. Ahmed. el-Binâye şerhu'l-Hidâye. thk. Emin Salih Şaban. 13 Cilt. Beyrut: Dâru'l-Kütübi'l-ilmiyye, 2000.

Bâbertî, Ekmelüddîn Muhammed b. Mahmud. el-'Inâye. 8 Cilt. Bulak: Matbaatü'l-Kübra'lEmîriyye, 1315.

Baktır, Mustafa. "Kaide”. Türkiye Diyanet Vakfi İslam Ansiklopedisi. 24/205-210. İstanbul: TDV Yayınları, 2001.

Buhârî, Ebû Abdillâh Muhammed b. İsmail. el-Câmi'u's-sahîh. Dimașk-Beyrut: Dâru İbn Kesîr, 2002.

Burhânüddîn el-Buhârî, Mahmûd b. Ahmed el-Merğînânî. el-Muhîtu'l-Burhânî. 25 Cilt. Beyrut: İdâretü'l-Kur'ân ve'l-ulûmi'l-İslâmiyye, 2004.

Çeker, Orhan. "Mecelle'de Ele Alınmayan Üç Konu: Faiz Sarf ve Karz". Ahmet Cevdet Paşa (1823-1895). Ankara: Türkiye Diyanet Vakfı Yayınları, 1997.

Damad Efendi, Şeyhîzâde Abdurrahman. Mecma'u'l-enhur fì șerhi Mülteka'l-ebhur. 4 Cilt. Beyrut: Dâru'l-Kütübi'l-ilmiyye, 1998.

Dârimî, Ebû Muhammed Abdullah b. Abdirrahmân. es-Sünen. thk. Hüseyin Selîm Esed elDârânî. Riyad: Dâru'l-Muğnî, 2000.

Enderpetî, Ferîdüddin Âlim b. el-Alâ. el-Fetâva't-Tatarhâniyye. 20 Cilt. Diyobend: Mektebetü Zekeriyyâ, 2010.

Gazzî, Muhammed Sıdkî b. Ahmed el-Burnû. Mevsû'atü'l-kavâ'idi'l-fikhiyye. 12 Cilt. Riyad: Mektebetü't-Tevbe, 1997.

Gezgin, Yusuf Erdem. Altın Mübadele İşlemleri: İslam Hukuku Açısından Bir Değerlendirme. İstanbul: İktisat Yayınları, 2020.

Haddâd, Ebû Bekir b. Ali. el-Cevheretü’n-neyyire. thk. İlyas Kaplan. 2 Cilt. Beyrut: Dâru'l-Kütübi'l-ilmiyye, 2006.

Hamevî, Ebü'l-Abbâs Șihâbüddîn Ahmed b. Muhammed. Gamzü 'uyûni'l-besâir șerhu kitâbi'lEşbâh ve'n-nezâir. 4 Cilt. Beyrut: Dâru'l-Kütübi'l-ilmiyye, 1985.

Haskefî, Alâüddîn Muhammed b. Ali. ed-Dürru'l-muhtâr șerhu Tenvîri'l-ebsâr. thk. Abdülmünim Halil İbrahim. Beyrut: Dâru'l-Kütübi'l-ilmiyye, 2002.

Heyet. el-Fetâva'l-Hindiyye / el-Fetâva'l-'Âlemgîriyye. 6 Cilt. Bulak: Matbaatü'l-Kübra'lEmîriyye, 1310.

Heyet. Ma'leme Zayed li'l-kavâ'idi'l-fikhiyye ve'l-usûliyye. 41 Cilt. Abu Dabi: Müessesetü Zayed b. Sultân, 2013.

İbn Âbidîn, Muhammed Emin b. Ömer b. Abdilaziz ed-Dımașkî. Reddü'l-muhtâr 'ale'd-Dürri'lmuhtâr șerhi Tenvîri'l-ebsâr. thk. Adil Ahmed Abdülmevcud - Ali Muhammed Muavvaz. 10 Cilt. Riyad: Dâru Âlemi'l-kütüb, 2003.

İbn Âbidînzâde, Alâüddîn Muhammed b. Muhammed Emîn ed-Dimașkî. Kurretü 'uyûni'l-ahyâr tekmiletü Reddi'l-muhtâr 'ale'd-Dürri'l-muhtâr șerhi Tenvîri'l-ebsâr (Reddu'l-muhtâr ile birlikte). 2 Cilt. Riyad: Dâru Âlemi'l-kütüb, 2003.

İbn Ebî Şeybe, Ebû Bekr Abdullâh b. Muhammed el-Kûfî. el-Musannef fi'l-ehâdîs ve'l-âsâr. 7 Cilt. Beyrut: Dâru't-Tâc, 1989.

İbn Kudâme, Ebû Muhammed Muvaffakuddîn Abdullâh b. Ahmed. el-Muğnî. thk. Abdulfettâh el-Hulv - Abdullah et-Türkî. 15 Cilt. Riyad: Dâru Âlemi'l-kütüb, 1997.

İbn Mâce, Ebû Abdillâh Muhammed b. Yezid el-Kazvînî. es-Sünen. thk. Beșşâr Avvâd Ma'rûf. 6 Cilt. Beyrut: Dâru'l-Cîl, 1998.

İbn Nüceym, Sirâcüddîn Ömer b. İbrahim el-Mısrî. en-Nehru'l-fâik șerhu Kenzi'd-dekâik. thk. Ahmed İzzû İnaye. 3 Cilt. Beyrut: Dâru'l-Kütübi'l-ilmiyye, 2002.

İbn Nüceym, Zeynulâbidîn b. İbrahim. el-Bahru'r-râik şerhu Kenzi'd-dekâik. 9 Cilt. Beyrut: Dârü'l-Kütübi'l-ilmiyye, 1997.

İbnü'l-Hümâm, Kemâlüddîn Muhammed b. Abdilvâhid es-Sivâsî. Fethu'l-kadîr. 8 Cilt. Bulak: Matbaatü'l-Kübra'l-Emîriyye, 1315. 
Huzeyfe Çeker. Use of the Concept 'Ribā Suspicion' in Hanafi Fiqh Books | 91

Kadızâde, Ahmed Şemseddin. Netâicü'l-efkâr tekmiletü Fethi'l-kadîr. Bulak: Matbaatü'lKübra'l-Emîriyye, 1315.

Kâsânî, Alâüddîn Ebû Bekir b. Mesûd. Bedâi'u's-sanâii fí tertîbi'ş-șerâii' 7 Cilt. Beyrut: Dâru'lKütübi'l-ilmiyye, 1986.

Mâverdî, Ebü'l-Hasen Ali b. Muhammed. el-Hâvi'l-kebîr. thk. Âdil Ahmed Abdülmevcûd - Ali Muhammed Muavvaz. 18 Cilt. Beyrut: Dâru'l-Kütübi'l-ilmiyye, 1994.

Mergînânî, Ebu'l-Hasan Burhaneddin Ali b. Ebî Bekr. el-Hidâye șerhu Bidâyeti'l-mübtedî. 8 Cilt. Karaçi: İdaretü'l-Kur'an ve'l-Ulumi'l-İslâmiyye, 1417.

Mevsılî, Ebu'l-Fadl Mecdüddîn Abdullah b. Mahmûd. el-Muhtâr li'l-fetvâ. 5 Cilt. Beyrut: Dâru'lKütübi'l-ilmiyye, ts.

Meydânî, Abdulganî el-Ganîmî. el-Lübâb fî şerhi'l-Kitâb. 4 Cilt. Beyrut: el-Mektebetü'l-İlmiyye, ts.

Molla Hüsrev, Mehmed b. Ferâmurz. Dürerü'l-hükkâm fî şerhi Gureri'l-ahkâm. 2 Cilt. Karaçi: Mir Muhammed Kitabevi, ts.

Müslim, Ebü'l-Hüseyn Müslim b. el-Haccâc el-Kușeyrî. el-Câmi'u's-sahîh. 5 Cilt. Kahire: Dâru'lHadîs, 1991.

Müzenî, Ebû İbrâhîm İsmâîl b. Yahyâ. el-Muhtasar. Beyrut: Dâru'l-Kütübi'l-ilmiyye, 1998.

Nesâî, Ebû Abdirrahmân Ahmed b. Şuayb. es-Sünen. Riyad: Mektebetü'l-Meârif, 1997.

Nesefî, Ebû Hafs Necmüddîn Ömer b. Muhammed. Tilbetü't-talebe fi'l-Istılâhâti'l-fikhiyye. Beyrut: Dâru'n-Nefâis, 1995.

Nevevî, Ebû Zekeriyya Yahyâ b. Șeref. el-Mecmû' șerhu'l-Mühezzeb. 20 Cilt. Dâru'l-Fikr, ts.

Özer, Hasan. "İbn-i Kemâl ve 'Riba' Adlı Risalesi”. İslam Hukuku Araştırmaları Dergisi 16 (2010), 157-186.

Pala, Ali İhsan. İslâm Hukukunda İhtiyat İlkesi. Ankara: Fecr Yayınları, 2009.

Remlî, Ebû Abdillâh Șemsüddîn Muhammed b. Ahmed. Nihâyetü'l-muhtâc ilâ șerhi'l-Minhâc. 8 Cilt. Beyrut: Dâru'l-Kütübi'l-ilmiyye, 2003.

Samar, Mahmut. Akitlerde Şart Hürriyeti. Kahramanmaraş: SAMER Yayınları, ts.

Sem'ânî, Ebu'l-Muzaffer Mansûr b. Muhammed. el-İstılâm fi'l-hilâf beyne'l-İmâmeyn eș-Sâfi'î ve Ebî Hanîfe. thk. Nâyif b. Nâfi' el-Ömerî. 4 Cilt. Kahire: Dâru'l-Menâr, 1992.

Semerkandî, Ebû Bekir Alâüddîn Muhammed b. Ahmed. Tuhfetü'l-fukahâ. 3 Cilt. Beyrut: Dâru'l-Kütübi'l-ilmiyye, 1984.

Serahsî, Ebû Bekir Şemsü'l-eimme Muhammed b. Ebî Sehl. el-Mebsût. 31 Cilt. Beyrut: Dâru'lMarife, 1989.

Şâfiî, Ebû Abdillâh Muhammed b. İdris. el-Ümm. 8 Cilt. Beyrut: Dâru'l-Marife, ts.

Şelebî, Ebü'l-Abbas Șehâbûddîn Ahmed b. Muhammed. Hâşiye 'alâ Tebyîni'l-hakâik. 6 Cilt. Bulak: Matbaatü'l-Kübra'l-Emîriyye, 1315.

Şeybânî, Muhammed b. el-Hasen. el-Asl. thk. Mehmet Boynukalın. 12 Cilt. Beyrut: Dâru İbn Hazm, 2012.

Tirmizî, Ebû İsâ Muhammed b. İsâ. es-Sünen. Riyad: Mektebetü'l-Meârif, 1997.

Zeylaî, Fahruddîn Osman b. Ali. Tebyînü'l-hakâik fî șerhi Kenzi'd-dekâik. 6 Cilt. Bulak: Matbaatü'l-Kübra'l-Emîriyye, 1315. 